\title{
The Alpha, Beta and Gamma Antigens of Clostridium histolyticum (Weinberg \& Séguin, 1916)
}

\author{
BY C. L. OAKLEY AND G. HARRIET WARRACK \\ The Wellcome Research Laboratories (Biological Division), Beckenham, Kent
}

SUMMARY: Three antigenic components $(\alpha, \beta, \gamma)$ are present in toxic culturefiltrates of Clostridium histolyticum. Of these $\alpha$ is the lethal and necrotizing toxin, $\beta$ is a collagenase, and $\gamma$ is a cysteine-activated proteinase which attacks altered collagen (e.g. hide-powder or azocoll) but not native collagen. The $\beta$ and $\gamma$-enzymes both attack gelatin. By methods based on the properties of these antigens, $\mathrm{Cl}$. histolyticum antisera can be tested for the corresponding antibodies.

Weinberg \& Séguin (1916) described as Bacillus histolyticus an obligate anaerobe isolated by them from patients with gas gangrene. The organism tended to occur in pairs, was rather small (3-5 $\mu \times 0.5-0.7 \mu)$, richly flagellate, vigorously motile in young cultures and in effusions, had large subterminal endospores and was actively proteolytic. It was pathogenic for guinea-pigs, mice and rabbits, less so for rats; intramuscular injection of culture led to extensive local destruction, splitting of the skin, extrusion of a haemorrhagic muscle pulp, denudation of the bone and sometimes to auto-amputation through a joint. Neither putrid changes nor gas formation occurred in the liquefying area, which frequently spread far beyond the injected limb.

There have been few subsequent records of the isolation of the organism, now called Clostridium histolyticum (see Peterson \& Hall, 1922-3; Hall, 1923-4; Torrey, 1925). Other work has shown that it digests native and denatured proteins to amino-acids with production of ammonia, that it clots milk and later digests the clot (Blanc \& Pozerski, 1920a) and haemolyses sheep red cells (Kahn, 1922). There is some question whether $\mathrm{Cl}$. histolyticum is saccharolytic; Kahn (1922) found that it fermented maltose, lactose, xylose and inulin with production of acid; Hall (1922-3) found that all five strains examined by him failed to ferment glucose, fructose, maltose, lactose, sucrose, salicin, glycerol or inulin. These differences may perhaps be explained by Hoogerheide's work (1987) on the dissociation of $\mathrm{Cl}$. histolyticum into saccharolytic non-pathogenic strains resembling $\mathrm{Cl}$. sporogenes, and typical non-saccharolytic pathogenic $\mathrm{Cl}$. histolyticum.

Descriptions of the microscopic changes produced by infection with $\mathrm{Cl}$. histolyticum are given by Nasta (1922), who remarked on the extension of oedema far beyond the infecting organisms, and by Beckwith \& MacKillop (1923-4).

\section{Products detected in culture filtrates}

The lethal and necrotizing toxins. Weinberg \& Séguin (1916) observed that the culture-filtrates were toxic for guinea-pigs and rabbits; intravenous injection of sufficiently strong filtrates killed the animal in a few minutes; paralysis was followed by respiratory arrest. No author appears to have described a necrotic 
lesion following intracutaneous injection of $\mathrm{Cl}$. histolyticum filtrates, but Pasternack (1940) showed that the necrotic and degenerative changes produced in the internal organs by infection with the organism could be almost completely duplicated by intravenous injection of filtrates. Subcutaneous injection of filtrate led to boggy oedema and purplish discoloration of the skin in 3-4 days, followed by linear rupture of the skin and discharge of 'beet-soup fluid'; most animals then recovered, though some suffered exposure of bone or spontaneous amputation. Pozerski \& Guélin (1938b) noted the production of an 'escarre' after subcutaneous injection of $\mathrm{Cl}$. histolyticum filtrate into guinea-pigs. Gildemeister \& Schlossberger (1932) showed that filtrates injected into the cornea led to swelling of the cornea and to formation of bubbles in it. No attempt seems to have been made to decide whether all these effects are due to the same substance.

Proteinases. Blanc \& Pozerski (1920a) showed that filtrates of $\mathrm{Cl}$. histolyticum digested proteins less readily than cultures did, and that, except in the case of gelatin, which was digested to amino-acids, the products of digestion were peptones. Filtrates of $\mathrm{Cl}$. sporogenes were similarly proteolytic, but their activity was inhibited by normal serum and by ovalbumin, neither of which had any effect on the proteolytic effect of $\mathrm{Cl}$. histolyticum filtrates (Blanc \& Pozerski, 1920 b; Pozerski \& Guélin, 1938a). Bessey \& King (1934) showed that Cl. histolyticum filtrates attacked gelatin much more vigorously than did filtrates of $\mathrm{Cl}$. sporogenes; no pepsin or papain type enzymes or polypeptidases were present in filtrates of $72 \mathrm{hr}$. cultures. Weil \& Kocholaty (1937) found that filtrates of 3-day cultures of $\mathrm{Cl}$. histolyticum contained a proteinase, active against casein, clupein, Witte peptone and egg-albumin, that was activated by ferrous ions, by cysteine (better by both together) by manganese, nickel, cobalt and copper ions. All sulphydryl compounds used activated it (even the relatively insoluble thio- $\beta$-naphthol) but not hydrogen sulphide or cyanide. Oxygenation reversed the ferrous ion + cysteine effect; iodoacetic acid did not; high concentrations of hydrogen peroxide decreased the activity irreversibly. According to Kocholaty, Weil \& Smith (1938) the proteinase appeared $6 \mathrm{hr}$. after inoculation of the medium, and was at its maximum after about $15 \mathrm{hr}$.; its concentration ran roughly parallel with the amount of bacterial growth, and there was no evidence that it was an intracellular enzyme. Kocholaty \& Weil (1938) contended that by repeated subculture on gelatin or casein, $\mathrm{Cl}$. histolyticum could be 'trained' to produce enzymes which attacked gelatin but not casein, and vice versa. This remarkable specificity of the proteinase could be abolished, either by growing the organism in gelatin plus the amino-acids necessary to make gelatin 'equivalent' to casein, or by activating the filtrates from either casein or gelatin cultures with ferrous ions and cysteine; the filtrates then attacked gelatin or casein indifferently (see also Kocholaty \& Krejci, 1948). The proteinase was neutralized by $\mathrm{Cl}$. histolyticum antisera.

On the other hand, Maschmann (1938) found that filtrates of Cl. histolyticum contained extracellular proteinases not activated by cysteine, and that only in the later stages of growth was a proteinase secreted that was activated by cysteine. van Heyningen (1940) claimed to have reconciled these discrepancies 
by showing that colonies of $\mathrm{Cl}$. histolyticum varied greatly in the proportions of two proteinases produced by them, and that it was possible to obtain strains which produced in early growth an extracellular proteinase activatable by cysteine and inhibited by iodoacetic acid, while older cultures (after $12 \mathrm{hr}$. incubation) contained an intracellular enzyme inhibited by cysteine.

A fibrinolysin has been described by Carlen (1939) and by Reed, Orr \& Brown (1943).

Collagenases. It was noted by Weinberg \& Séguin (1916) that while injection of cultures of $\mathrm{Cl}$. histolyticum produced extensive destruction of muscle, filtrates attacked the connective tissue only (see also Hall \& Peterson, 1922-3). This difference must, however, be relative, for Pasternack (1940) found that subcutaneous injection of filtrates led not only to extensive oedema with swelling and pseudo-colloid degeneration of collagen and elastin fibres, with hydropic degeneration of the epidermis and dissociation of epithelial glandular and endothelial cells, but also to loss of striation of muscle cells and of their normal staining capacity, with subsequent myolysis and haemorrhage. There was no change in the nuclei.

The presence of a collagenase in $\mathrm{Cl}$. histolyticum cultures was first recorded by Jennison (1945) who showed that they disintegrated heated tendo Achillis of cow, and also Highberger's purified steer-hide collagen sterilized by heating; their activity was enhanced by thiolacetate. Later (1947), Jennison provided more convincing evidence by showing that filtrates attacked fine strands of clean unprocessed beef tendon, whether it was sterilized by dry heat or not; he followed the process of digestion by determining the loss of weight in the collagen used. Evans (1947) observed that $\mathrm{Cl}$. histolyticum produced a substance which attacked hide-powder and was distinct from the lethal toxin. This substance might be a collagenase or one of the proteinases that attacks degraded collagen.

\section{EXPERIMENTAL}

Cultural methods and production of toxins. Eight strains of $\mathrm{Cl}$. histolyticum were obtained as desiccates from the Culture Collection of these Laboratories. It seems reasonably certain that five of these are distinct strains; no evidence can be provided to support the distinctness of the others. Smooth colonies on agar plates were selected from all the strains and grown in 50 ml. quantities of Brewer's medium for $24 \mathrm{hr}$., or in larger volumes of nutrient broth or a papain digest of horse muscle for $16-24 \mathrm{hr}$. The cultures were largely freed from bacteria by the addition of 'Hyflo' Supercel (Johns, Manville; 5 g./l.) and filtration through paper, and if necessary sterilized by candling. In general, the methods were similar to those found satisfactory for producing the toxic culture filtrates of $\mathrm{Cl}$. oedematiens (Oakley, Warrack \& Clarke, 1947).

Sera. We had only six sera, produced some years before by Mr A. T. Glenny, F.R.S., by immunizing horses with toxic culture-filtrates of $\mathrm{Cl}$. histolyticum and with toxoids made from them. Testing for antibodies was carried out by conventional methods, using serum RR 2001 (100 units) as standard. 


\section{Examination of culture-filtrates for toxins}

Lethal toxins. Filtrate + serum mixtures were allowed to stand for $30 \mathrm{~min}$. at room temperature, then injected intravenously in $0.5 \mathrm{ml}$. volumes into mice weighing $16-20 \mathrm{~g}$. Level of test, $0.25,0.5$ or 1 unit injected, according to strength of filtrate; standard indicating effect, death within $48 \mathrm{hr}$. of half the mice injected.

Table 1. Values of sera in lethal tests against Clostridium histolyticum filtrates

\begin{tabular}{cccc} 
& \multicolumn{3}{c}{ Serum values against filtrate } \\
\cline { 2 - 4 } Serum & CN 647 & CN 919 & CN 949 \\
RR 2001 & 100 & 100 & 100 \\
RR 2005 & 230 & 240 & 260 \\
RR 2008 & 25 & 30 & 25 \\
RR 2035 & 530 & 570 & 600 \\
RR 8003 & 55 & 50 & 60 \\
RR 8006 & 70 & 75 & 75
\end{tabular}

Only three filtrates were lethal in sufficiently small amounts to make reasonably accurate testing possible. Table 1 shows that the serum values in lethal tests were, within the rather considerable experimental error, the same whichever filtrate was used. The lethal toxin for which the end-point was determined was therefore probably the same for all three filtrates; there was no evidence of a second lethal antigen.

Necrotizing toxins. Filtrate + serum mixtures were allowed to stand for $30 \mathrm{~min}$. at room temperature, then injected intracutaneously in volumes of $0.2 \mathrm{ml}$. into guinea-pigs. Level of test $0.2,0.4$ or 0.8 unit injected, according to strength of filtrate; standard indicating effect, a small necrotic lesion. (In under-neutralized mixtures a characteristic circular oedematous purple necrotic lesion was produced.)

Table 2. Comparison of anti-lethal and anti-necrotizing values of sera, to show that the lethal toxin of Clostridium histolyticum has necrotizing properties

\begin{tabular}{|c|c|c|c|c|}
\hline \multirow[b]{2}{*}{ Serum } & \multirow{2}{*}{$\begin{array}{c}\text { Serum } \\
\text { values } \\
\text { in lethal } \\
\text { tests }\end{array}$} & \multicolumn{3}{|c|}{$\begin{array}{c}\text { Serum values in necrotizing tests } \\
\text { against filtrate }\end{array}$} \\
\hline & & CN 647 & CN 919 & CN 948 \\
\hline RR 2001 & 100 & 100 & 100 & 100 \\
\hline RR 2005 & 240 & 240 & 250 & 250 \\
\hline RR 2008 & 27 & 25 & 24 & 25 \\
\hline RR 2035 & 570 & 550 & 550 & 530 \\
\hline RR 8003 & $\mathbf{5 5}$ & $\mathbf{5 5}$ & 52 & 46 \\
\hline RR 8006 & 73 & 65 & 65 & 60 \\
\hline
\end{tabular}

Table 2 shows that serum values in necrotizing tests against all the three filtrates used were constant for any particular serum and equal to the anti-lethal values; thus the lethal toxin is also necrotizing. 
Collagenases. Filtrate + serum mixtures were allowed to stand at room temperature for $30 \mathrm{~min}$. in tubes $6 \mathrm{~cm}$. long $\times 0.8 \mathrm{~cm}$. internal diameter (Lambeth tubes); they were then incubated overnight with pieces of fresh guinea-pig muscle or collagen paper (Oakley, Warrack \& van Heyningen, 1946; Delaunay, Guillaumie \& Delaunay, 1949). Level of test 1 unit; standard indicating effect: a well-marked softening of muscle or disintegration of collagen paper.

Table 3. Comparison of anti-lethal values of sera with those obtained in musclesoftening and collagen paper tests to show that the collagenase $(\beta)$ is distinct from the lethal toxin $(\alpha)$

\begin{tabular}{|c|c|c|c|c|c|c|c|}
\hline \multirow[b]{3}{*}{ Serum } & \multirow{3}{*}{$\begin{array}{c}\text { Serum } \\
\text { values } \\
\text { in lethal } \\
\text { tests }\end{array}$} & \multicolumn{6}{|c|}{ Serum values against filtrate } \\
\hline & & \multicolumn{2}{|c|}{$\begin{array}{c}\text { NX } 729 \\
\text { using as indicator }\end{array}$} & \multicolumn{2}{|c|}{$\begin{array}{c}\text { NX 730 } \\
\text { using as indicator }\end{array}$} & \multicolumn{2}{|c|}{$\begin{array}{c}\text { CN 647 } \\
\text { using as indicator }\end{array}$} \\
\hline & & $\begin{array}{c}\text { Fresh } \\
\text { muscle }\end{array}$ & $\begin{array}{c}\text { Collagen } \\
\text { paper }\end{array}$ & $\begin{array}{c}\text { Fresh } \\
\text { muscle }\end{array}$ & $\begin{array}{c}\text { Collagen } \\
\text { paper }\end{array}$ & $\begin{array}{l}\text { Fresh } \\
\text { muscle }\end{array}$ & $\begin{array}{c}\text { Collagen } \\
\text { paper }\end{array}$ \\
\hline RR 2001 & 100 & 100 & 100 & 100 & 100 & 100 & 100 \\
\hline RR 2005 & 240 & $\mathbf{3 3 0}$ & 350 & 320 & 250 & 310 & $\mathbf{3 5 0}$ \\
\hline RR 2008 & 27 & $\mathbf{3 7 0}$ & $\mathbf{3 7 0}$ & 330 & $\mathbf{3 7 0}$ & 320 & $\mathbf{3 7 0}$ \\
\hline RR 2035 & $\mathbf{5 7 0}$ & 220 & 240 & 200 & 210 & 250 & 230 \\
\hline RR 8003 & $\mathbf{5 5}$ & 180 & 180 & 160 & 200 & - & $\mathbf{2 6 0}$ \\
\hline RR 8006 & 73 & 170 & 170 & 170 & 160 & 150 & 180 \\
\hline
\end{tabular}

Table 3 shows that the serum values against collagen paper or guinea-pig muscle as indicators are independent of the filtrate used and agree with one another, though they bear no relationship to the values obtained in lethal tests. The collagenase $(\beta)$ is therefore distinct from the lethal and necrotizing toxin $(\alpha)$.

Oakley, Warrack \& Warren (1948) showed that $\mathrm{Cl}$. roelchii collagenase ( $\kappa$-toxin) has lethal and necrotizing activities; unfortunately the very low anti-lethal values of our $\mathrm{Cl}$. histolyticum antisera, as compared with their anti-collagenase values, have made it impossible so far to decide whether Cl. histolyticum collagenase is lethal and necrotizing.

All the $\mathrm{Cl}$. histolyticum antisera contained small amounts of $\mathrm{Cl}$. welchii $\kappa$ antitoxin; comparison of the $\boldsymbol{C l}$. welchii anti- $\kappa$ values with the $\boldsymbol{C l}$. histolyticum anti- $\beta$ values shows that there is no relationship between them; the collagenases of $\mathrm{Cl}$. welchii and $\mathrm{Cl}$. histolyticum are antigenically distinct.

Other proteinases. Filtrate serum mixtures were allowed to stand for $30 \mathrm{~min}$. at room temperature, and were then incubated overnight in a water-bath at $37^{\circ}$ with 'azocoll' (Oakley et al. 1946); this material is attacked by several proteolytic enzymes which do not attack collagen (Todd, 1947; Oakley et al. 1948). Level of test one unit; standard indicating effect, diffusion of a small amount of colour from the azocoll.

Table 4 shows that serum values against azocoll as indicator are divisible into two groups, those corresponding to the anti- $\beta$ values, and those that are much lower. The lower values are characteristic of two sera RR 2005 and RR 2035, and it is noticeable that though their values differ according to the filtrate used for test, the values for the two sera are substantially equal against any given 
Table 4. Comparison of anti-collagenase values of sera and those found in azocoll tests, to show evidence of an enzyme $(\gamma)$ attacking azocoll but not collagen

\begin{tabular}{|c|c|c|c|c|c|}
\hline \multirow[b]{2}{*}{ Serum } & \multirow{2}{*}{$\begin{array}{c}\text { Anti-collagenase } \\
\text { values* }\end{array}$} & \multicolumn{4}{|c|}{ Serum values in azocoll tests against filtrate } \\
\hline & & CN $647 *$ & CN 919* & NX 729† & NX 730† \\
\hline RR 2001 & 100 & 100 & 100 & 100 & 100 \\
\hline RR 2005 & $\mathbf{3 5 0}$ & 160 & 160 & 140 & 140 \\
\hline RR 2008 & $\mathbf{3 8 0}$ & $\mathbf{3 7 0}$ & 450 & 300 & 250 \\
\hline RR 2035 & 250 & 160 & 210 & 150 & 170 \\
\hline RR 8003 & 210 & 320 & 230 & 225 & 210 \\
\hline RR 8006 & 160 & 190 & 180 & 190 & 190 \\
\hline
\end{tabular}

filtrate. In other words, the end-point given by these two sera in azocoll tests is for a proteinase $(\gamma)$ capable of attacking azocoll but not collagen; the anti- $\gamma$ values of RR 2005 and RR 2035 are approximately equal, their anti- $\beta$ values are not.

Addition of $0.05 \mathrm{M}$ cysteine to one of the culture filtrates (from Cl. histolyticum $\mathrm{CN}$ 647) had no effect on its test dose or on its standard indicating dose against collagen paper; its activity against azocoll was slightly increased, and its test dose against this material was diminished to about one-half, using serum RR 2001 as standard. As the test dose against collagen paper was unaffected by addition of cysteine, one may reasonably assume that the collagenase test dose against azocoll was unaffected also; therefore, since the test dose of the cysteine activated filtrate was diminished to one-half in azocoll tests, any serum giving the collagenase end-point would appear to double in value when tested against it. Table 5 shows that sera RR 8003 and RR 8006

Table 5. Comparison of anti-collagenase values of sera with those obtained in azocoll tests, to give further evidence of the existence of $\gamma$, and of its activation by cysteine. The relevant end-points are indicated in brackets

\begin{tabular}{|c|c|c|c|c|}
\hline \multirow[b]{2}{*}{ Serum } & \multirow{2}{*}{$\begin{array}{l}\text { Anti- } \\
\text { collagenase } \\
\text { values }\end{array}$} & \multicolumn{3}{|c|}{ Serum values in azocoll tests against filtrate $\mathrm{CN} 647$} \\
\hline & & Unmodified & $+0.05 \mathrm{M}$ cysteine & $+0.01 \mathrm{M}$ iodoacetate \\
\hline RR 2001 & 100 & $100(\beta$ or $\gamma)$ & $100(\gamma)$ & $100(\beta$ or $\gamma)$ \\
\hline RR 2005 & 320 & $160(\gamma)$ & $160(\gamma)$ & $150(\gamma)$ \\
\hline RR 2008 & $\mathbf{3 6 0}$ & $370(\beta$ or $\gamma)$ & $360(\gamma)$ & $345(\beta)$ \\
\hline RR 2035 & 225 & $160(\gamma)$ & $180(\gamma)$ & $140(\gamma)$ \\
\hline RR 8003 & 260 & $320(\beta)$ & $\mathbf{5 5 0}(\beta)$ & $290(\beta)$ \\
\hline RR 8006 & 180 & $190(\beta)$ & $410(\beta)$ & $190(\beta)$ \\
\hline
\end{tabular}

have apparently doubled their values when tested against cysteine-activated filtrate in azocoll tests; thus they are giving the collagenase $(\beta)$ end-point. When all the serum values are divided by two, so that the values of RR 8003 and RR 8006 are decreased to their usual anti- $\beta$ values, all the other sera show values less than their anti- $\beta$ values; their end-points are thus clearly for an antigen other than $\beta$. It cannot certainly be stated what this antigen is, but 
since sera RR 2005 and RR 2035 give equal values against cysteine-activated filtrate, it is probable that the end-point given by sera other than RR 8003 and RR 8006 is the $\gamma$-end-point, and that $\gamma$-antigen is activated by cysteine. To look at it in another way, if before activation with cysteine the $\beta: \gamma$-antigen ratio in $\mathrm{CN} 647$ was $1: 1$, after activation it was $1: 2$, with corresponding effects on the values of sera titrated against it (see Oakley, 1943).

It follows, moreover, that if the standard serum RR 2001 is given an anti- $\gamma$ value of 100 units, the anti- $\gamma$ values of the remaining sera will be those found in azocoll tests against cysteine-activated culture filtrate of $\mathrm{CN} 647$, except for RR 8003 and RR 8006, whose anti- $\gamma$ values will be greater than 550 units and greater than 410 units respectively.

For filtrate $\mathrm{CN} 647$ neither the test dose against collagen paper nor the test dose against azocoll was affected by $0.01 \mathrm{~m}$ iodoacetate; presumably neither $\beta$ nor $\gamma$-antigen is activated or inhibited by it. Serum values against iodoacetatetreated filtrate did not differ from those against untreated filtrate. This filtrate therefore appeared to contain an enzyme $(\gamma)$ similar to the cysteine-activated proteinase described by Weil \& Kocholaty (1937) and by Maschmann (1938); no evidence has been obtained of enzymes inhibited by cysteine or iodoacetic acid; we hope to carry out a more thorough examination of filtrates for such proteinases in the near future.

Gelatinases. Serum values were determined in parallel in azocoll and gelatin-agar tests (Oakley et al. 1948) against two filtrates NX 729 and NX 730. Level of test in gelatin agar tests 1 unit; standard indicating effect, a clear zone of convenient size. The serum values (Table 6) show that in azocoll tests these

Table 6. Comparison of anti- $\beta$ and anti- $\gamma$ values of sera with those obtained in azocoll and gelatin-agar tests to show that both $\beta$ and $\gamma$ attack azocoll and gelatin

\begin{tabular}{|c|c|c|c|c|c|c|}
\hline \multirow[b]{3}{*}{ Serum } & \multirow{3}{*}{$\begin{array}{l}\text { Anti }-\beta \\
\text { values }\end{array}$} & \multirow{3}{*}{$\begin{array}{l}\text { Anti- } \gamma \\
\text { values }\end{array}$} & \multicolumn{4}{|c|}{ Serum values against filtrate } \\
\hline & & & \multicolumn{2}{|c|}{$\begin{array}{l}\text { NX } 729 \text { using } \\
\text { as indicator }\end{array}$} & \multicolumn{2}{|c|}{$\begin{array}{l}\text { NX } 730 \text { using } \\
\text { as indicator }\end{array}$} \\
\hline & & & Azocoll & Gelatin-agar & Azocoll & Gelatin-agar \\
\hline RR 2001 & 100 & 100 & 100 & $100(\beta$ or $\gamma)$ & 100 & 100 \\
\hline RR 2005 & 320 & 160 & 140 & $170(\gamma)$ & 140 & 160 \\
\hline RR 2008 & $\mathbf{3 6 0}$ & $\mathbf{3 6 0}$ & 300 & $360(\beta)$ & 250 & $\mathbf{3 5 0}$ \\
\hline RR 2035 & 225 & 150 & 150 & $160(\gamma)$ & 130 & 170 \\
\hline RR 8003 & 260 & $>\mathbf{5 5 0}$ & 225 & $240(\beta)$ & 210 & 270 \\
\hline RR 8006 & 180 & $>410$ & 190 & $230(\beta)$ & 190 & 230 \\
\hline
\end{tabular}

filtrates behaved very much like the previous non-activated filtrates: RR 2005 and RR 2035 gave the $\gamma$-end-point, RR 8003 and RR 8006 the $\beta$-end-point, while RR 2001 and RR 2008 gave either the $\beta$ or $\gamma$-end-point. Serum values in gelatin agar tests were, as compared with the standard, slightly higher than the values in azocoll tests. The difference was small, and will need much more work to confirm. In general the results are of the same order in gelatin-agar and in azocoll tests, and the simplest explanation is that the same end-point is determined in both. If this is so, both $\beta$ and $\gamma$ attack gelatin. 
We wish to express our very grateful thanks to Mrs Patricia Clarke for much bacteriological assistance, to her and to Miss H. E. Ross for producing numerous toxic culture-filtrates, and to Miss Marian E. Warren for considerable technical assistance.

\section{REFERENCES}

Branc, J. \& Pozerski, E. (1920a). Sur les ferments protéolytiques de quelques anaérobies pathogènes. C.R. Soc. Biol., Paris, 83, 1343.

Blanc, J. \& Pozersiri, E. (1920b). Sur les ferments protéolytiques du B. sporogenes et du B. histolyticus. C.R. Soc. Biol., Paris, 83, 1369.

BeCKWITH, T. D. \& MacKillop, G. (1923-4). Effects produced by injection of B. histolyticus. J. med. Res. 44, 311.

Bessey, O. \& KInG, C. G. (1934). Proteolytic and deaminising enzymes of $\mathrm{Cl}$. sporogenes and Cl. histolyticum. J. infect. Dis. 54, 128.

Carlen, S. A. (1939). Fibrinolytic properties of filtrates of $\mathrm{Cl}$. histolyticum in normal saline and dog serum. Proc. Soc. exp. Biol., N.Y., 40, 39.

Demaunay, M., Guillaumie, M. \& Delaunay, A. (1949). A propos des collagénases bacteriennes. Ann. Inst. Pasteur, 76, 16.

Evans, D. G. (1947). The production by certain species of Clostridium of enzymes disintegrating hide-powder. J. gen. Microbiol. $1,378$.

Gibdemeister, E. \& Schlossberger, H. (1932). Ueber die Wirkung des Toxins der Erreger der Gasbrandgruppe auf die Kaninchenhornhaut. Zbl. Bakt. (1, Abt. Orig.), 126, 527.

Hall, I. C. (1922-3). The failure of fermentation reactions with $B$. histolyticus. Proc. Soc. exp. Biol., N.Y., 20, 503.

HaIl, I. C. (1923-4). Recovery of B. histolyticus from human faeces. Proc. Soc. exp. Biol., N.Y., 21, 198.

Hall, I. C. \& Petergon, E. (1922-3). A note on the mechanism of the peculiar lesions produced by Bacillus histolyticus. Proc. Soc. exp. Biol., N.Y., 20, 508.

Heyningen, W. E. van (1940). The proteinases of $\mathrm{Cl}$. histolyticum. Biochem. J. 34, 1540.

HoogerheIde, J. C. (1937). Variability in morphological and biochemical properties of $\mathrm{Cl}$. histolyticum (Weinberg \& Séguin). J. Bact. 34, 387.

Jennison, M. W. (1945). Bacterial collagenase. J. Bact. 50, 369.

Jennison, M. W. (1947). The collagenase activity of culture filtrates of $\mathrm{Cl}$. histolyticum. J. Bact. 54, 55.

KAHN, M. C. (1922). A cultural study of anaerobic spore-bearing bacteria with strains isolated by the Barber single-cell technique. J. med. Res. 43, 155.

Kocholaty, W. \& KREJCI, L. E. (1948). The activation mechanism and physicochemical properties of $C l$. histolyticum proteinase. Arch. Biochem. 18, 1 .

Kocholaty, W. \& WeIL, L. (1938). Enzymic adaptation in Cl. histolyticum. Biochem. J. $32,1696$.

Kocholaty, W., Weir, L. \& Smith, L. (1938). Proteinase secretion and growth of Cl. histolyticum. Biochem. J. 32, 1685.

Maschuann, E. (1938). Ueber Bakterienproteasen. IV. Mitteilung. Die Proteasen des B. histolyticus. Biochem. Z. 295, 391.

Nasta, M. (1922). Contribution à l'étude de l'action du B. histolyticus sur les tissus. C.R. Soc. Biol., Paris, 87, 279.

OAkney, C. L. (1943). The toxins of Cl. reelchii. A critical review. Bull. Hyg., Lond., $18,781$.

Oakuey, C. L., Warrack, G. H. \& Clarke, P. H. (1947). The toxins of $\mathrm{Cl}$. oedematiens (Cl. novyi). J. gen. Microbiol. $1,91$.

Oakrey, C. L., Warrack, G. H. \& Heyningen, W. E. van (1946). The collagenase ( $\kappa$-toxin) of $\mathrm{Cl}$. welchii type A. J. Path. Bact. 58, 229. 
OAkney, C. L., Warrack, G. H. \& Warren, M. E. (1948). The kappa and lambda antigens of $\mathrm{Cl}$. welchii. J. Path. Bact. 60, 495.

Pasternack, J. G. (1940). The experimental pathological changes produced by the toxin of $\mathrm{Cl}$. histolyticum in animals. Publ. Hlth Rep., Wash., 55, 775.

Peterson, E. \& Hall, I. C. (1922-3). The isolation of B. histolyticum from soil in California. Proc. Soc. exp. Biol., N.Y., 20, 502.

Pozerski, E. \& Gúkín, A. (1938a). Action empêchante de l'ovalbumine crue sur les ferments gélatinolytiques de quelques microbes anaérobies. C.R. Soc. Biol., Paris, 128, 504.

Pozersis, E. \& Gúturn, A. (1938b). Contribution à l'étude des filtrats de quelques microbes anaérobies. Gelatinase et pouvoir escarrifiant. C.R. Soc. Biol., Paris, $128,842$.

Raed, G. B., OrR, J. H. \& Brown, H. J. (1943). Fibrinolysins from gas gangrene anaerobes. J. Bact. 46, 475 .

TopD, E. W. (1947). A study of the inhibition of streptococcal proteinase by sera of normal and immune animals and of patients infected with group $A$ haemolytic streptococci. J. $\exp$. Med. 85, 591.

ToRRey, J. C. (1925). Habitat of B. histolyticus in human intestine. J. infect. Dis. 36,517 .

Wen, L. \& Kocholaty, W. (1937). Studies on proteinase of $\mathrm{Cl}$. histolyticum. Biochem. J. 31, 1255.

Weinberg, M. \& Steutn, P. (1916). Contribution à l'étiologie de la gangrène gazeuse. C.R. Acad. Sci., Paris, 163, 449.

(Received 14 January 1950) 